\title{
Correction to: Probing the Processes: Longitudinal Qualitative Research on Social Determinants of HIV
}

\author{
Clare Barrington $^{1}\left[\right.$ - Alana Rosenberg ${ }^{2} \cdot$ Deanna Kerrigan $^{3} \cdot$ Kim M. Blankenship $^{4}$
}

Published online: 13 September 2021

(c) The Author(s) 2021

\section{Correction to: AIDS and Behavior \\ https://doi.org/10.1007/s10461-021-03240-w}

The article "Probing the Processes: Longitudinal Qualitative Research on Social Determinants of HIV", written by Clare Barrington · Alana Rosenberg · Deanna Kerrigan · Kim M. Blankenship was originally published electronically on the publisher's internet portal on 27th March 2021 without open access. With the author(s)' decision to opt for Open Choice the copyright of the article changed on 6th August 2021 to (C) The Author(s) 2021 and the article is forthwith distributed under a Creative Commons Attribution.

The original article has been corrected.
Open Access This article is licensed under a Creative Commons Attribution 4.0 International License, which permits use, sharing, adaptation, distribution and reproduction in any medium or format, as long as you give appropriate credit to the original author(s) and the source, provide a link to the Creative Commons licence, and indicate if changes were made. The images or other third party material in this article are included in the article's Creative Commons licence, unless indicated otherwise in a credit line to the material. If material is not included in the article's Creative Commons licence and your intended use is not permitted by statutory regulation or exceeds the permitted use, you will need to obtain permission directly from the copyright holder. To view a copy of this licence, visit http://creativecommons.org/licenses/by/4.0/.

Publisher's Note Springer Nature remains neutral with regard to jurisdictional claims in published maps and institutional affiliations.

The original article can be found online at https://doi.org/10.1007/ s10461-021-03240-w.

Clare Barrington

cbarring@email.unc.edu

1 Department of Health Behavior, Gillings School of Global Public Health, University of North Carolina at Chapel Hill, CB 7440, Chapel Hill, NC 27599, USA

2 Department of Epidemiology of Microbial Diseases, Yale School of Public Health, Yale University, New Haven, CT, USA

3 Department of Prevention and Community Health, Milken Institute School of Public Health, George Washington University, Washington, DC, USA

4 Department of Sociology, American University, Washington, DC, USA 